\title{
COMPARISON OF CARBON AND NITROGEN DETERMINATION METHODS FOR SAMPLES OF A PALEUDULT SUBJECTED TO NO-TILL CROPPING SYSTEMS
}

\author{
Jeferson Dieckow ${ }^{1 *}$; João Mielniczuk²; Heike Knicker³; Cimélio Bayer²; Deborah Pinheiro \\ Dick ${ }^{4}$; Ingrid Kögel-Knabner ${ }^{3}$ \\ ${ }^{1}$ UFPR - Depto. de Solos e Engenharia Agrícola, R. dos Funcionários 1540 - 80035-050 - Curitiba, PR - Brasil. \\ ${ }^{2}$ UFRGS - Depto. de Solos, C.P. 15100 - 91501-970 - Porto Alegre, RS - Brasil. \\ ${ }^{3}$ TUM - Lehrstuhl für Bodenkunde, D-85350 - Freising-Weihenstephan - Germany \\ ${ }^{4}$ UFRGS - Depto. de Físico-Química, 90001-970 - Porto Alegre, RS - Brasil. \\ *Corresponding author <jefersondieckow@ufpr.br>
}

\begin{abstract}
Organic carbon (C) concentration evaluated by the Walkley-Black method, and total nitrogen (N) concentration determined by Kjeldahl method, were compared with corresponding results of $\mathrm{C}$ and $\mathrm{N}$ concentrations obtained through the dry combustion method (Elementar Vario EL analyzer), using samples of ten soil layers down to the depth of $107.5 \mathrm{~cm}$ of a kaolinitic Typic Paleudult (220-418 g clay $\mathrm{kg}^{-1}$ along the profile) subjected to no-till cropping systems [fallow bare soil, pigeon pea (Cajanus cajan L. Millsp.) plus maize, and lablab (Lablab purpureum L. Sweet) plus maize]. A close correlation $\left(\mathrm{R}^{2} \geq 0.96\right)$ was observed between the $\mathrm{C}$ results of the Walkley-Black and dry combustion methods, but a correction was suggested to be applied to $C$ results of Walkley-Black $\left(C=1.05 C_{\text {w.Black }}+0.47\right)$. A close correlation $\left(\mathrm{R}^{2} \geq 0.96\right)$ was also found between results of Kjeldahl-N and dry combustion- $\mathrm{N}$, but no correction was necessary to be applied. The relationships between results of Walkley-Black and dry combustion and between results of Kjeldahl and dry combustion did not change among soil samples from different management systems, in disagreement to findings of a previous study where results of analytical C recovery were influenced by samples from different managements, supposedly because changes in lability or recalcitrance of organic matter might have affected the wet combustion reactions. A poor correlation $\left(\mathrm{R}^{2}=0.42\right)$ was found between the $\mathrm{C}: \mathrm{N}$ ratios based on Walkley-Black and Kjeldahl analysis and the C: $\mathrm{N}$ ratios based on dry combustion analysis. The methods for $\mathrm{C}$ and $\mathrm{N}$ determination did not affect the interpretation of the effects of management systems on soil $\mathrm{C}$ and $\mathrm{N}$ stocks.
\end{abstract}

Key words: Walkley-Black, Kjeldahl, wet combustion, dry combustion

\section{COMPARAÇÃO DE MÉTODOS DE DETERMINAÇÃO DE CARBONO E NITROGÊNIO EM AMOSTRAS DE ARGISSOLO SOB PLANTIO DIRETO}

RESUMO: Resultados de concentração de carbono (C), obtidos pelo método Walkley-Black, e resultados de concentração de nitrogênio $(\mathrm{N})$ total, determinados pelo método Kjeldahl, foram comparados com os correspondentes resultados de $\mathrm{C}$ e $\mathrm{N}$ obtidos pelo método de combustão seca (analisador Elementar Vario EL), utilizando-se amostras de dez camadas de um Argissolo Vermelho até a profundidade de $107.5 \mathrm{~cm}$ (220-418 g argila $\mathrm{kg}^{-1}$ ao longo do perifl), manejado em sistemas de culturas de plantio direto [solo descoberto, guandu (Cajanus cajan L. Millsp.) mais milho, e lab lab (Lablab purpureum L. Sweet) mais milho]. Alta correlação $\left(\mathrm{R}^{2} \geq 0.96\right)$ foi observada entre os resultados de C-Walkley-Black e C-combustão seca. Uma correção foi sugerida para os resultados de C-Walkley-Black $\left(\mathrm{C}=1.05 \mathrm{C}_{\mathrm{w} \text {.Black }}\right.$ $+0.47)$. Elevada correlação $\left(R^{2} \geq 0.96\right)$ também foi observada entre os resultados de N-Kjeldahl e Ncombustão seca, não sendo necessária a aplicação de uma correção aos resultados de N-Kjeldahl. A relação entre os resultados de Walkley-Black e combustão seca e entre os resultados de Kjeldahl e combustão seca não mudaram entre amostras de solo de diferentes sistemas de manejo, diferindo dos resultados de um trabalho anterior onde a recuperação analítica de C foi influenciada por amostras oriundas de diferentes manejos, supostamente por alterações na labilidade ou recalcitrância da matéria orgânica terem afetado as reações de combustão úmida. Uma baixa correlação $\left(R^{2}=0.42\right)$ foi observada entre a relação C:N baseada nas análises Walkley-Black e Kjeldahl e a relação C:N baseada na combustão seca. Os métodos de determinação de $\mathrm{C}$ e $\mathrm{N}$ não afetaram as interpretações do efeito de sistemas de manejo sobre os estoques de $\mathrm{C}$ e $\mathrm{N}$ no solo.

Palavras-chave: Walkley-Black, Kjeldahl, combustão úmida, combustão seca 


\section{INTRODUCTION}

The reliability of methods for carbon (C) and nitrogen $(\mathrm{N})$ measurements is of fundamental concern in soil organic matter studies because $\mathrm{C}$ and $\mathrm{N}$ analyses constitute the first analytical step towards soil organic matter quantification and characterization. Automated dry combustion methods, although being of easy and simple operation, not requiring excessive amounts of reagents, presenting high accuracy and not having the problem related to chemical waste disposal, are not always feasible for small laboratories due to acquisition costs of the equipment. Thus, in many soil laboratories the conventional Walkley-Black and Kjeldahl methods for $\mathrm{C}$ and $\mathrm{N}$ analysis, respectively, are still routinely being employed.

Although the $\mathrm{C}$ concentration results given by the Walkley-Black rapid dichromate oxidation method are generally lower than those obtained through the reference dry combustion methods (McGeehan \& Naylor, 1988; Mikhailova et al., 2003) a high correlation is commonly found between these two methods (Mikhailova et al., 2003; Pérez et al., 2001). To overcome the problem of incomplete $\mathrm{C}$ recovery which leads to the underestimation of $\mathrm{C}$ concentrations by Walkley-Black method, the analytical results of this technique are corrected by a factor, commonly reported as 1.30 when no external heat is applied (Nelson \& Sommers, 1996). A correction factor of 1.63 was proposed for a Russian Chernozem (Mikhailova et al., 2003), while a factor of 1.12 was suggested for subtropical soils of the State of Rio Grande do Sul, Brazil (Tedesco et al., 1995), but with application of external heat.

The Kjeldahl method of soil $\mathrm{N}$ analysis is being commonly employed in laboratories not equipped with a dry combustion automated analyzer, although more personal labor and reagents are required. In organic soils or soils with high organic matter contents, the results of $\mathrm{N}$ concentration obtained through the Kjeldahl method are generally lower than results of dry combustion (Bremner \& Shaw, 1958; Stewart et al., 1963). For mineral soils or soils with low organic matter contents, results have been comparable between these two methods (Bremner \& Shaw, 1958; Stewart et al., 1963).

Regarding the influence that soil samples originated from different management systems might have on analytical results of wet combustion or digestion, Diaz-Zorita (1999) showed that C recovery by WalkleyBlack method was $15 \%$ lower compared to dry combustion method in samples of a pasture land in Argentina Pampa, while for agricultural land samples, results were comparable among the two methods. This dif- ference among samples of distinct management systems was attributed to the greater amounts of chemical stable organic compounds in pasture than in crop residues. This influence of samples from different management on $\mathrm{C}$ results could not be however confirmed in a study conducted in a Russian Chernozem (Mikhailova et al., 2003).

The hypothesis of this study is that different analytical methods for soil $\mathrm{C}$ and $\mathrm{N}$ determinations (dry and wet combustion) provide different $\mathrm{C}$ and $\mathrm{N}$ concentration results, and thus corrections to a standard method should be necessary. Therefore, this study compares the results of soil organic $\mathrm{C}$ concentration and stock obtained by Walkley-Black method and the results of total $\mathrm{N}$ concentration and stock determined by Kjeldahl method with the respective $\mathrm{C}$ and $\mathrm{N}$ concentrations and stocks obtained through the automated dry combustion method (Elementar Vario EL analyzer), using samples of a subtropical kaolinitic Typic Paleudult subjected to different no-till cropping systems.

\section{MATERIAL AND METHODS}

\section{Soil samples}

Soil samples were collected from a long-term experiment (18 years) located in Eldorado do Sul, State of Rio Grande do Sul, Brazil (3051' S and 5138’ W). The soil was a kaolinitic Typic Paleudult, and the climate as humid-subtropical (Cfa, Köppen). Ten soil layers were sampled down to the $107.5-\mathrm{cm}$ depth, in three replicates of three no-till cropping systems: bare soil; pigeon pea (Cajanus cajan L. Millsp.) plus maize (Zea mays L.) $[\mathrm{P}+\mathrm{M}]$; and lablab (Lablab purpureum $\mathrm{L}$. Sweet) plus maize $[\mathrm{L}+\mathrm{M}]$. The $\mathrm{P}+\mathrm{M}$ and $\mathrm{L}+\mathrm{M}$ systems were conducted under two $\mathrm{N}$ levels ( 0 and 180 $\mathrm{kg} \mathrm{N} \mathrm{ha}{ }^{-1}$ applied to the maize crops). Soil samples were air dried and ground in a mortar to pass through a $0.50-\mathrm{mm}$ mesh sieve.

The clay fraction of the $0-20 \mathrm{~cm}$ layer is constituted mainly by kaolinite $\left(720 \mathrm{~g} \mathrm{~kg}^{-1}\right)$, but contains also iron oxides $\left(109 \mathrm{~g} \mathrm{~kg}^{-1}\right)$ and other unidentified minerals (Bayer, 1996). An increment in clay content from $221 \mathrm{~g} \mathrm{~kg}^{-1}$ in the top layer to $418 \mathrm{~g} \mathrm{~kg}^{-1}$ in the deepest layer was found, due to the presence of the argillic horizon (Table 1). Soil texture analyses were performed using the hydrometer with a Bouyoucos' scale, (Gee \& Bauder, 1986). More details about the experiment and sampling are given elsewhere (Diekow et al., 2005).

\section{Carbon analyses}

The Walkley-Black procedure of C analysis was based on the description of Nelson \& Sommers (1996), with adaptation to the employment of exter- 
nal heat (Tedesco et al., 1995). The heating was provided by swirling the suspension over a Bunsen burner-flame after the addition of $\mathrm{H}_{2} \mathrm{SO}_{4}$ and was controlled so that the initial temperature of $120^{\circ} \mathrm{C}$ could rise to $150^{\circ} \mathrm{C}$ within one minute. Soil samples of about $0.50 \mathrm{~g}$ were used, but for some treatments with high $\mathrm{C}$ concentration the analysis had to be repeated using $0.25 \mathrm{~g}$.

Dry combustion method $\left(975^{\circ} \mathrm{C}\right)$ was performed with a Vario EL II analyzer (Elementar Analysensysteme, Hanau, Germany) detecting carbon as $\mathrm{CO}_{2}$. The detection limit for carbon is $0.4 \mu \mathrm{g}$. Soil samples of about $30 \mathrm{mg}$ were used. Since no carbonate $\mathrm{C}$ is present in this Paleudult (Brasil, 1973), the total $\mathrm{C}$ is referred as the organic C. Total C stocks were calculated for the $0-27.5 \mathrm{~cm}$ layer, after considering the soil bulk density of each layer (Table 2). Soil density down to the $27.5 \mathrm{~cm}$ depth was determined as suggested by Bayer (1996), and in no-N treatments,

Table 1 - Average particle-size distribution in the sampled soil layers.

\begin{tabular}{|c|c|c|c|}
\hline Soil layer & Sand $\varnothing$ s.d. & Silt $\varnothing$ s.d. & Clay $\varnothing$ s.d. \\
\hline $\mathrm{cm}$ & \multicolumn{3}{|c|}{ - $\mathrm{g} \mathrm{kg}^{-1}-\ldots$} \\
\hline $0-2.5$ & $536 \varnothing 20$ & $243 \varnothing 25$ & $221 \varnothing 5$ \\
\hline $2.5-7.5$ & $547 \varnothing 14$ & $233 \varnothing 21$ & $220 \varnothing 8$ \\
\hline $7.5-17.5$ & $525 \varnothing 9$ & $217 \varnothing 12$ & $258 \varnothing 16$ \\
\hline $17.5-27.5$ & $499 \varnothing 23$ & $215 \varnothing 14$ & $287 \varnothing 24$ \\
\hline $27.5-37.5$ & $480 \varnothing 34$ & $198 \varnothing 12$ & $322 \varnothing 45$ \\
\hline $37.5-47.5$ & $460 \varnothing 23$ & $181 \varnothing 18$ & $359 \varnothing 18$ \\
\hline $47.5-57.5$ & $425 \varnothing 20$ & $178 \varnothing 15$ & $398 \varnothing 21$ \\
\hline $57.5-67.5$ & $426 \varnothing 27$ & $166 \varnothing 17$ & $408 \varnothing 15$ \\
\hline $67.5-87.5$ & $407 \varnothing 24$ & $178 \varnothing 20$ & $415 \varnothing 35$ \\
\hline $87.5-107.5$ & $414 \varnothing 23$ & $167 \varnothing 20$ & $418 \varnothing 39$ \\
\hline
\end{tabular}

s.d. = standard deviation

Table 2 - Soil bulk density within the $27.5 \mathrm{~cm}$ layer, determined according to the core method, for treatments of bare soil, pigeon pea plus maize $(\mathrm{P}+\mathrm{M})$ and lablab plus maize $(\mathrm{L}+\mathrm{M})$ no-till systems, under two nitrogen levels $\left(0 \mathrm{~kg} \mathrm{~N} \mathrm{ha}^{-1}\right.$ - No N, and $180 \mathrm{~kg} \mathrm{~N} \mathrm{ha}^{-1}$ - With N). Original data from Bayer (1996).

\begin{tabular}{|c|c|c|c|c|c|}
\hline \multirow{2}{*}{ Soil layer } & \multicolumn{3}{|c|}{ No N } & \multicolumn{2}{|c|}{ With N } \\
\hline & Bare soil & $\mathrm{P}+\mathrm{M}$ & $\mathrm{L}+\mathrm{M}$ & $\mathrm{P}+\mathrm{M}$ & $\mathrm{L}+\mathrm{M}$ \\
\hline $\mathrm{cm}$ & - $-\ldots$ & $-\ldots-1$ & $\mathrm{t} \mathrm{m}^{-3}$ & 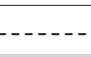 & -...- \\
\hline $0-2.5$ & 1.42 & 1.44 & 1.55 & 1.44 & 1.55 \\
\hline $2.5-7.5$ & 1.58 & 1.65 & 1.64 & 1.65 & 1.64 \\
\hline $7.5-17.5$ & 1.60 & 1.65 & 1.64 & 1.65 & 1.64 \\
\hline $17.5-27.5$ & 1.60 & 1.65 & 1.63 & 1.65 & 1.63 \\
\hline
\end{tabular}

according to the core method (Blake \& Hartage, 1986). For $\mathrm{N}$-fertilized treatments, considered the same bulk density of no-N treatments was considered.

\section{Nitrogen analyses}

The Kjeldahl semimicro procedure was based on acid digestion followed by steam distillation of the $\mathrm{NH}_{3}$ formed after addition of alkali (Bremner, 1965). The dry combustion was carried out simultaneously with the $\mathrm{C}$ analysis, in the same Vario EL analyzer, which has a detection limit of $1 \mu \mathrm{g}$ for $\mathrm{N}$. The total $\mathrm{N}$ stocks in the $0-27.5 \mathrm{~cm}$ layer were calculated according to the same procedure for total C.

\section{Statistical analysis}

Data were submitted to analysis of variance to assess the significance of the effects of cropping systems and $\mathrm{N}$ fertilization levels on the $\mathrm{C}$ and $\mathrm{N}$ concentrations and stocks measured through the different analytical methods. Analysis of variance (ANOVA) was carried out according to the employed split-plot design, considering the cropping system factor as the main plot and $\mathrm{N}$ level as sub-plots. The soil layer factor was not considered in ANOVA. Means were compared by using the Tukey test $(P=0.05)$, and linear regressions were made between results of WalkleyBlack and dry combustion, and between Kjeldahl and dry combustion methods. The confidence intervals of the angular and linear coefficients of these regressions were calculated at $P<0.05$, across the three experimental replicates.

\section{RESULTS AND DISCUSSION}

\section{Comparison of methods for $\mathrm{C}$ determination}

The results of $\mathrm{C}$ concentration obtained through the Walkley-Black method correlated well $\left(R^{2} \geq 0.96\right)$ with results of $C$ concentration obtained through dry combustion technique, for soil samples of all cropping systems (Figures 1a, 1b and 1c). The regressions found between these two methods were practically the same in the three cropping systems (Figures $1 \mathrm{a}, 1 \mathrm{~b}$ and $1 \mathrm{c}$ ), showing that results of $\mathrm{C}$ recovery by the Walkley-Black method compared to the reference dry combustion method were not influenced by samples originated from different managements. The Walkley-Black C recovery was also not affected by land use and soil management systems for a Russian Chernozem (Mikhailova et al., 2003), but was for a Typic Hapludoll in Argentina Pampa, where the chemical stable compounds of organic matter occurring after the application of some managements has supposedly reduced the Walkley-Black C recovery (Diaz-Zorita, 1999). 
Since the relationship between Walkley-Black and dry combustion remains the same across samples of different management systems, a general regression was fitted considering all the treatments together (Figure 1d). In most of the samples, C concentration determined through Walkley-Black method was lower than that obtained through dry combustion (Figure 1), possibly because of incomplete oxidation of the total organic C in the Walkley-Black procedure (McGeehan \& Naylor, 1988; Nelson \& Sommers, 1996). By taking the inverse of the linear regression in Figure 1d, a correction equation is thus proposed to be applied on the $\mathrm{C}$ concentration results of Walkley-Black: $\mathrm{C}=$ $1.05 \mathrm{C}_{\mathrm{w} . \text { Black }}+0.47$.

The $C$ concentrations of the two top layers as determined through dry combustion were affected by cropping systems and $\mathrm{N}$ fertilization levels, so that higher concentrations were found for soils under $\mathrm{P}+\mathrm{M}$ and $\mathrm{L}+\mathrm{M}$ or $\mathrm{N}$ fertilized, compared to the bare soil or soils without $\mathrm{N}$ fertilization (Table 3 ). The same trend was observed for $\mathrm{C}$ concentrations as determined by the Walkley-Black procedure, except of a lack of significance for the difference between fertilized and nonfertilized treatments in the top layer of $\mathrm{P}+\mathrm{M}$ and in the second layer of $\mathrm{L}+\mathrm{M}$ systems (Table 3 ).

The statistical trends for results of $\mathrm{C}$ concentration between cropping systems and between $\mathrm{N}$ fertilization levels were comparable for the two methods (Table 3). This was also observed for results of C stocks in the $0-27.5 \mathrm{~cm}$ layer, the layer which nearly corresponds to the $0-30 \mathrm{~cm}$ depth used in soil C inventory surveys (IPCC, 1996) (Table 4). Therefore, the methods for soil $\mathrm{C}$ determinations did not affect the interpretation of the effects of management systems in this kaolinitic Paleudult. This differs from the findings of Diaz-Zorita (1999) and Brye \& Slaton
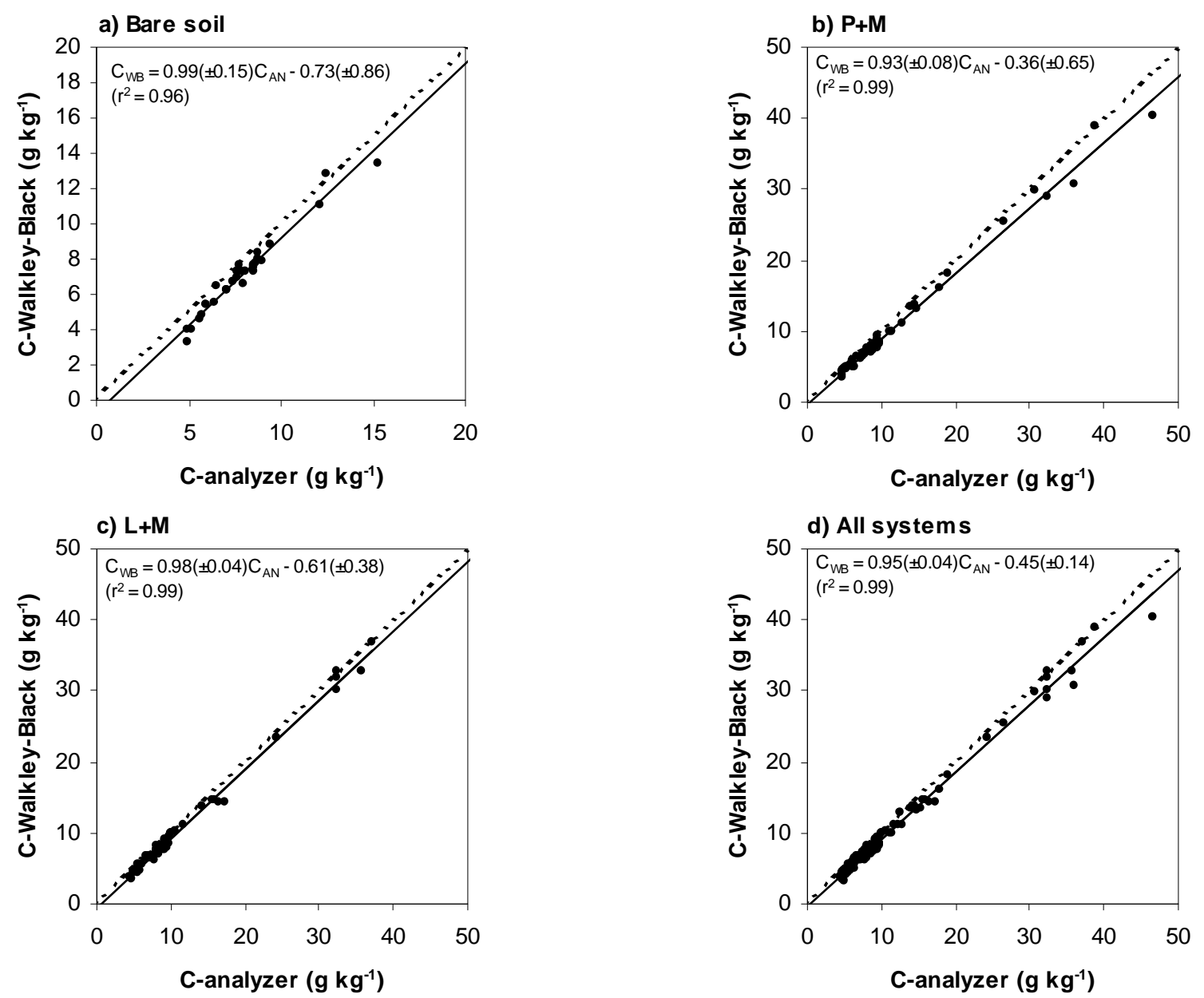

Figure 1 - Relationship between C concentrations obtained by the Walkley-Black method and C concentrations obtained by a dry combustion method (analyzer) in (a) bare soil ( $\mathrm{n}=30$ ), (b) $\mathrm{P}+\mathrm{M}$ system ( $\mathrm{n}=60)$, (c) $\mathrm{L}+\mathrm{M}$ system ( $\mathrm{n}=60)$ and (d) all systems $(n=150)$. For $P+M$ and $L+M$, results of both $N$ levels are included. " $C_{W B}$ ” means $C-W a l k l e y$ Black, " $C_{A N}$ ” means $\mathrm{C}$-analyzer. The values in parenthesis following the \pm signal refer to the confidence interval $(P<0.05)$ of the angular or linear coefficient of the regression. 
Table 3 - Carbon concentrations in bare soil, pigeon pea plus maize $(\mathrm{P}+\mathrm{M})$ and lablab plus maize $(\mathrm{L}+\mathrm{M})$ systems as measured by dry combustion and Walkley-Black methods.

\begin{tabular}{|c|c|c|c|c|c|}
\hline \multirow{2}{*}{ Soil layer } & \multicolumn{3}{|c|}{ No $\mathrm{N}$} & \multicolumn{2}{|c|}{ With $\mathrm{N}$} \\
\hline & Bare soil & $\mathrm{P}+\mathrm{M}$ & $\mathrm{L}+\mathrm{M}$ & $\mathrm{P}+\mathrm{M}$ & $\mathrm{L}+\mathrm{M}$ \\
\hline $\mathrm{cm}$ & \multicolumn{5}{|c|}{ - g C kg $\mathrm{kg}^{-1 \mathrm{a}}$} \\
\hline \multicolumn{6}{|c|}{ Dry combustion } \\
\hline $0-2.5$ & $13.3 \mathrm{~B}$ & $32.6 \mathrm{Ab}$ & $29.6 \mathrm{Ab}$ & $37.8 \mathrm{a}$ & $35.1 \mathrm{a}$ \\
\hline $2.5-7.5$ & $8.9 \mathrm{~B}$ & $13.8 \mathrm{Ab}$ & $14.0 \mathrm{Ab}$ & $17.1 \mathrm{a}$ & $16.5 \mathrm{a}$ \\
\hline $7.5-17.5$ & $8.2 \mathrm{~A}$ & $9.2 \mathrm{Aa}$ & $9.6 \mathrm{Aa}$ & $10.7 \mathrm{a}$ & $10.0 \mathrm{a}$ \\
\hline $17.5-27.5$ & $8.6 \mathrm{~A}$ & $9.2 \mathrm{Aa}$ & $8.7 \mathrm{Ab}$ & $9.2 \mathrm{a}$ & $9.3 \mathrm{a}$ \\
\hline $27.5-37.5$ & $8.4 \mathrm{~B}$ & $9.5 \mathrm{Aa}$ & $8.8 \mathrm{ABa}$ & $9.1 \mathrm{a}$ & $9.1 \mathrm{a}$ \\
\hline $37.5-47.5$ & $7.8 \mathrm{~B}$ & $9.2 \mathrm{Aa}$ & $8.4 \mathrm{ABa}$ & $8.6 \mathrm{a}$ & $8.8 \mathrm{a}$ \\
\hline $47.5-57.5$ & $7.2 \mathrm{~A}$ & $8.2 \mathrm{Aa}$ & $7.8 \mathrm{Aa}$ & $8.7 \mathrm{a}$ & $8.2 \mathrm{a}$ \\
\hline $57.5-67.5$ & $6.3 \mathrm{~A}$ & $7.8 \mathrm{Aa}$ & $7.5 \mathrm{Aa}$ & $8.0 \mathrm{a}$ & $7.5 \mathrm{a}$ \\
\hline $67.5-87.5$ & $5.8 \mathrm{~A}$ & $6.6 \mathrm{Aa}$ & $5.8 \mathrm{Aa}$ & $6.0 \mathrm{a}$ & $6.2 \mathrm{a}$ \\
\hline $87.5-107.5$ & $5.0 \mathrm{~A}$ & $5.0 \mathrm{Aa}$ & $4.9 \mathrm{Aa}$ & $5.1 \mathrm{a}$ & $5.1 \mathrm{a}$ \\
\hline \multicolumn{6}{|c|}{ Walkley-Black } \\
\hline $0-2.5$ & $12.4 \mathrm{~B}$ & $31.2 \mathrm{Aa}$ & $28.8 \mathrm{Ab}$ & $33.6 \mathrm{a}$ & $33.8 \mathrm{a}$ \\
\hline $2.5-7.5$ & $8.3 \mathrm{~B}$ & $12.6 \mathrm{Ab}$ & $13.2 \mathrm{Aa}$ & $15.9 \mathrm{a}$ & $14.4 \mathrm{a}$ \\
\hline $7.5-17.5$ & $7.5 \mathrm{~A}$ & $8.4 \mathrm{Aa}$ & $9.1 \mathrm{Aa}$ & $9.6 \mathrm{a}$ & $9.4 \mathrm{a}$ \\
\hline $17.5-27.5$ & $7.7 \mathrm{~A}$ & $8.0 \mathrm{Aa}$ & $7.9 \mathrm{Aa}$ & $8.1 \mathrm{a}$ & $8.5 \mathrm{a}$ \\
\hline $27.5-37.5$ & $7.5 \mathrm{~A}$ & $8.1 \mathrm{Aa}$ & $7.9 \mathrm{Aa}$ & $7.8 \mathrm{a}$ & $8.2 \mathrm{a}$ \\
\hline $37.5-47.5$ & $7.1 \mathrm{~A}$ & $8.2 \mathrm{Aa}$ & $7.6 \mathrm{Aa}$ & $7.6 \mathrm{a}$ & $7.9 \mathrm{a}$ \\
\hline $47.5-57.5$ & $6.4 \mathrm{~A}$ & $7.1 \mathrm{Aa}$ & $7.2 \mathrm{Aa}$ & $7.4 \mathrm{a}$ & $7.5 \mathrm{a}$ \\
\hline $57.5-67.5$ & $5.8 \mathrm{~B}$ & $6.9 \mathrm{Aa}$ & $6.5 \mathrm{ABa}$ & $7.1 \mathrm{a}$ & $6.8 \mathrm{a}$ \\
\hline $67.5-87.5$ & $4.9 \mathrm{~A}$ & $5.7 \mathrm{Aa}$ & $5.2 \mathrm{Aa}$ & $5.2 \mathrm{a}$ & $5.5 \mathrm{a}$ \\
\hline $87.5-107.5$ & $3.8 \mathrm{~A}$ & $4.4 \mathrm{Aa}$ & $4.2 \mathrm{Aa}$ & $4.3 \mathrm{a}$ & $4.7 \mathrm{a}$ \\
\hline
\end{tabular}

${ }^{a}$ Values in rows followed by the same capital letter do not differ (Tukey test, $P=0.05$ ). This is a comparison between cropping systems. Values in rows followed by the same small letter, in the same cropping system, do not differ (Tukey test, $P=0.05$ ). This is a comparison between $\mathrm{N}$ levels.

Table 4 - Carbon stocks in the 0-27.5 cm layer of bare soil, pigeon pea+maize $(\mathrm{P}+\mathrm{M})$ and lablab+maize $(\mathrm{L}+\mathrm{M})$ systems as measured by dry combustion and Walkley-Black methods.

\begin{tabular}{|c|c|c|c|c|c|}
\hline \multirow{2}{*}{ Method } & \multicolumn{3}{|c|}{ No $\mathrm{N}$} & \multicolumn{2}{|c|}{ With N } \\
\hline & Bare soil & $\mathrm{P}+\mathrm{M}$ & $\mathrm{L}+\mathrm{M}$ & $\mathrm{P}+\mathrm{M}$ & $\mathrm{L}+\mathrm{M}$ \\
\hline & \multicolumn{5}{|c|}{$\ldots \ldots$ t C ha ${ }^{1}$ a $\ldots \ldots \ldots$} \\
\hline Dry combustion & $39 \mathrm{~B}$ & $54 \mathrm{Aa}$ & $53 \mathrm{Aa}$ & 61 a & 59 a \\
\hline Walkley-Black & $35 \mathrm{~B}$ & $49 \mathrm{Aa}$ & $50 \mathrm{Aa}$ & $54 \mathrm{a}$ & $54 \mathrm{a}$ \\
\hline
\end{tabular}

${ }^{a}$ Values in rows followed by the same capital letter do not differ (Tukey test, $P=0.05$ ). This is a comparison between cropping systems. Values in rows followed by the same small letter, in the same cropping system, do not differ (Tukey test, $P=0.05$ ). This is a comparison between $\mathrm{N}$ levels.

(2003), which showed influence of the analytical methodology (Walkley-Black and dry combustion) on the interpretations of their results in different land use systems and crop rotations.

\section{Comparison of methods for $\mathbf{N}$ determination}

Nitrogen concentrations obtained by dry combustion were highly correlated $\left(\mathrm{R}^{2} \geq 0.96\right)$ to those of the Kjeldahl method (Figure 2) and the regressions between them were very similar for the three cropping systems (Figures 2a, 2b and 2c). There was, however, a tendency of the results from Kjeldahl to become closer to those obtained by dry combustion, for the $\mathrm{L}+\mathrm{M}$ system (Figure 2c).

Total $\mathrm{N}$ concentration by the Kjeldahl method tended to be lower than those obtained via dry combustion, considering the results of all systems together (Figure 2d), but this cannot be considered significant according to the confidence interval, which showed that the angular coefficient did not differ from 1 and the linear coefficient did not differ from zero (Figure 2d). Therefore, no correction was necessary for the Kjeldahl-N results. The tendency, however, for the higher concentrations obtained by dry 

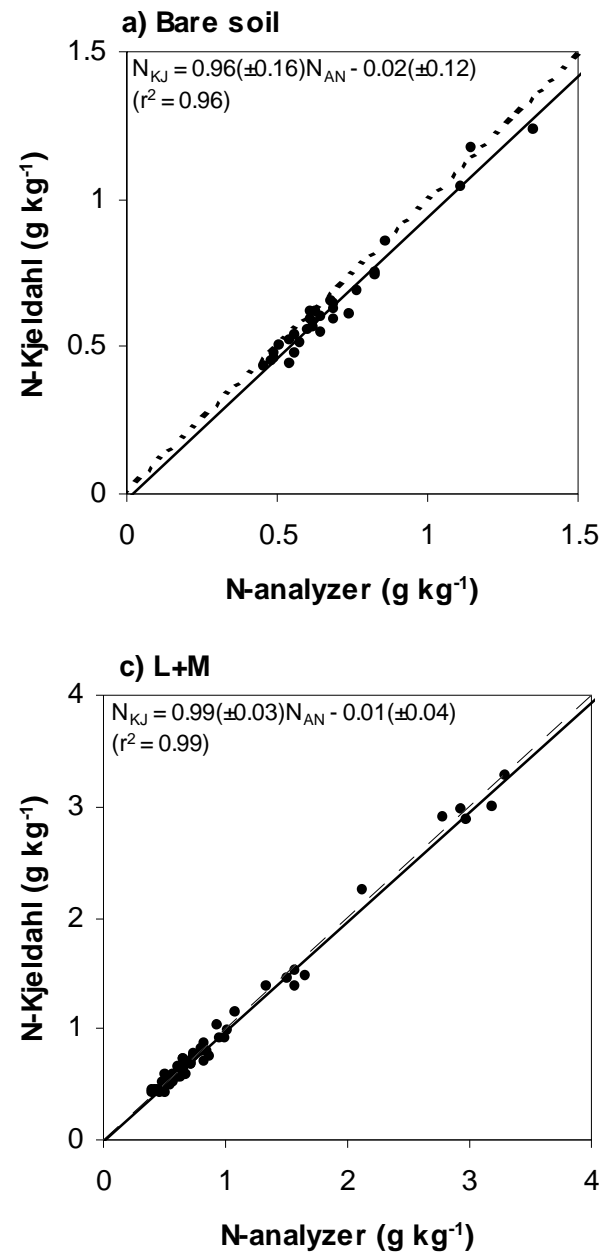

b) $\mathrm{P}+\mathrm{M}$
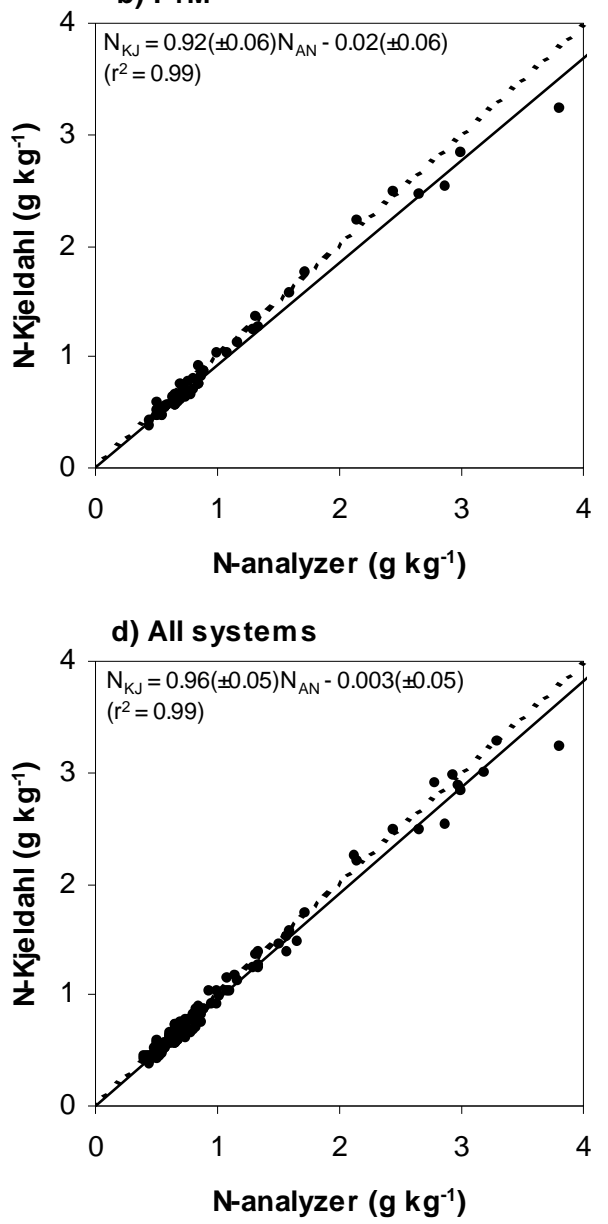

Figure 2 - Relationship between total N concentrations obtained by the Kjeldahl semimicro method and the dry combustion method (analyzer) in (a) bare soil ( $\mathrm{n}=30)$, (b) P+M system ( $\mathrm{n}=60)$, (c) $\mathrm{L}+\mathrm{M}$ system ( $=60)$ and $(\mathrm{d})$ all systems $(\mathrm{n}=150)$. For $\mathrm{P}+\mathrm{M}$ and $\mathrm{L}+\mathrm{M}$, results of both $\mathrm{N}$ levels are included. " $\mathrm{N}_{\mathrm{KJ}}$ " means $\mathrm{N}$-Kjeldahl, " $\mathrm{N}_{\mathrm{AN}}$ ” means $\mathrm{N}$-analyzer. The values in parenthesis following the \pm signal refer to the confidence interval $(P<0.05)$ of the angular or linear coefficient of the regression.

combustion could be related to a non quantitatively release of some refractory $\mathrm{N}$, or of $\mathrm{N}$ in $\mathrm{N}-\mathrm{O}$ structures of $\mathrm{NO}_{3}^{-}$(McGeehan \& Naylor, 1988; Bremner, 1965).

Similar to $\mathrm{C}$, the $\mathrm{N}$ concentrations in the two top layers as assessed by dry combustion were significantly higher for the $\mathrm{P}+\mathrm{M}$ and $\mathrm{L}+\mathrm{M}$ systems as compared to bare soil, and for fertilized soils than non fertilized treatments (Table 5). About the same statistical trend was observed for results of the Kjeldahl method, except for the top layer of $\mathrm{P}+\mathrm{M}$ and the second layer of $\mathrm{L}+\mathrm{M}$, where no differences were observed between fertilized and non-fertilized treatments (Table 5). In a general view, the statistical trends observed for the results of $\mathrm{N}$ concentration are relatively similar, either for dry combustion or Kjeldahl (Table 5). Similar statistical trends of the two methods were also observed for the results of total $\mathrm{N}$ stocks in the $0-27.5 \mathrm{~cm}$ layer (Table 6). This means that the interpretations of the effect of soil management on the $\mathrm{N}$ concentrations and stocks, as well as the conclusions drawn from these interpretations, are comparable irrespective if analysis were performed through dry combustion or Kjeldahl method.

\section{$\mathrm{C}: \mathrm{N}$ ratios}

One of the basic information in soil organic matter characterization studies is the $\mathrm{C}: \mathrm{N}$ ratio. There was a poor correlation $\left(R^{2}=0.42\right)$ between the $C: N$ ratios calculated from results of $\mathrm{C}$ and $\mathrm{N}$ obtained through dry combustion and those calculated from results of Walkley-Black and Kjeldahl methods (Figure 3a). The same trend was observed when the Walkley-Black-C concentrations were corrected by the respective correction equation $\left(\mathrm{C}=1.05 \mathrm{C}_{\mathrm{w} . \text { Black }}\right.$ +0.47 ) (Figure $3 b$ ) or when the Walkley-Black-C concentration was multiplied by the correction factor of 1.12 , as commonly performed for soils analy- 
Table 5 - Total nitrogen concentration in bare soil, pigeon pea plus maize $(\mathrm{P}+\mathrm{M})$ and lablab plus maize $(\mathrm{L}+\mathrm{M})$ samples as measured by dry combustion and Kjeldahl.

\begin{tabular}{|c|c|c|c|c|c|}
\hline \multirow{2}{*}{ Soil layer } & \multicolumn{3}{|c|}{ No $\mathrm{N}$} & \multicolumn{2}{|c|}{ With $\mathrm{N}$} \\
\hline & Bare soil & $\mathrm{P}+\mathrm{M}$ & $\mathrm{L}+\mathrm{M}$ & $\mathrm{P}+\mathrm{M}$ & $\mathrm{L}+\mathrm{M}$ \\
\hline \multicolumn{6}{|c|}{ - $\mathrm{g} \mathrm{kg}^{-1 \mathrm{a}}$} \\
\hline \multicolumn{6}{|c|}{ Dry combustion } \\
\hline $0-2.5$ & $1.20 \mathrm{~B}$ & $2.61 \mathrm{Ab}$ & $2.63 \mathrm{Ab}$ & $3.04 \mathrm{a}$ & $3.14 \mathrm{a}$ \\
\hline $2.5-7.5$ & $0.84 \mathrm{~B}$ & $1.28 \mathrm{ABb}$ & $1.36 \mathrm{Ab}$ & $1.54 \mathrm{a}$ & $1.56 \mathrm{a}$ \\
\hline $7.5-17.5$ & $0.73 \mathrm{~A}$ & $0.89 \mathrm{Aa}$ & $0.91 \mathrm{Aa}$ & $0.98 \mathrm{a}$ & $0.94 \mathrm{a}$ \\
\hline $17.5-27.5$ & $0.68 \mathrm{~A}$ & $0.81 \mathrm{Aa}$ & $0.76 \mathrm{Aa}$ & $0.81 \mathrm{a}$ & $0.84 \mathrm{a}$ \\
\hline $27.5-37.5$ & $0.65 \mathrm{~A}$ & $0.76 \mathrm{Aa}$ & $0.69 \mathrm{Aa}$ & $0.74 \mathrm{a}$ & $0.69 \mathrm{a}$ \\
\hline $37.5-47.5$ & $0.61 \mathrm{~B}$ & $0.72 \mathrm{Aa}$ & $0.65 \mathrm{ABa}$ & $0.68 \mathrm{a}$ & $0.68 \mathrm{a}$ \\
\hline $47.5-57.5$ & $0.61 \mathrm{AB}$ & $0.67 \mathrm{Aa}$ & $0.59 \mathrm{Ba}$ & $0.69 \mathrm{a}$ & $0.64 \mathrm{a}$ \\
\hline $57.5-67.5$ & $0.54 \mathrm{~A}$ & $0.65 \mathrm{Aa}$ & $0.59 \mathrm{Aa}$ & $0.67 \mathrm{a}$ & $0.62 \mathrm{a}$ \\
\hline $67.5-87.5$ & $0.52 \mathrm{~A}$ & $0.59 \mathrm{Aa}$ & $0.49 \mathrm{Aa}$ & $0.54 \mathrm{a}$ & $0.54 \mathrm{a}$ \\
\hline $87.5-107.5$ & $0.50 \mathrm{~A}$ & $0.50 \mathrm{Aa}$ & $0.44 \mathrm{Aa}$ & $0.50 \mathrm{a}$ & $0.48 \mathrm{a}$ \\
\hline \multicolumn{6}{|c|}{ Kjeldahl } \\
\hline $0-2.5$ & $1.15 \mathrm{~B}$ & $2.50 \mathrm{Aa}$ & $2.67 \mathrm{Ab}$ & $2.74 \mathrm{a}$ & $3.08 \mathrm{a}$ \\
\hline $2.5-7.5$ & $0.78 \mathrm{~B}$ & $1.24 \mathrm{Ab}$ & $1.33 \mathrm{Aa}$ & $1.52 \mathrm{a}$ & $1.45 \mathrm{a}$ \\
\hline $7.5-17.5$ & $0.65 \mathrm{~B}$ & $0.88 \mathrm{Aa}$ & $0.92 \mathrm{Aa}$ & $0.96 \mathrm{a}$ & 0.92 a \\
\hline $17.5-27.5$ & $0.61 \mathrm{~A}$ & $0.70 \mathrm{Aa}$ & $0.71 \mathrm{Aa}$ & $0.77 \mathrm{a}$ & $0.78 \mathrm{~b}$ \\
\hline $27.5-37.5$ & $0.60 \mathrm{~A}$ & $0.70 \mathrm{Aa}$ & $0.70 \mathrm{Aa}$ & $0.71 \mathrm{a}$ & $0.72 \mathrm{a}$ \\
\hline $37.5-47.5$ & $0.58 \mathrm{~A}$ & $0.66 \mathrm{Aa}$ & $0.64 \mathrm{Aa}$ & $0.65 \mathrm{a}$ & $0.66 \mathrm{a}$ \\
\hline $47.5-57.5$ & $0.56 \mathrm{~A}$ & $0.61 \mathrm{Aa}$ & $0.59 \mathrm{Aa}$ & $0.62 \mathrm{a}$ & $0.62 \mathrm{a}$ \\
\hline $57.5-67.5$ & $0.50 \mathrm{~B}$ & $0.58 \mathrm{Aa}$ & $0.56 \mathrm{ABa}$ & $0.58 \mathrm{a}$ & $0.57 \mathrm{a}$ \\
\hline $67.5-87.5$ & $0.48 \mathrm{~A}$ & $0.53 \mathrm{Aa}$ & 0.49 Аа & $0.54 \mathrm{a}$ & $0.50 \mathrm{a}$ \\
\hline $87.5-107.5$ & $0.44 \mathrm{~A}$ & $0.46 \mathrm{Aa}$ & $0.43 \mathrm{Aa}$ & $0.43 \mathrm{a}$ & $0.48 \mathrm{a}$ \\
\hline
\end{tabular}

avalues in rows followed by the same capital letter do not differ (Tukey test, $P=0.05$ ). This is a comparison between cropping systems. Values in rows followed by the same small letter, in the same cropping system, do not differ (Tukey test, $P=0.05$ ). This is a comparison between $\mathrm{N}$ levels.

Table 6 - Nitrogen stocks in the $0-27.5$ cm layer of bare soil, pigeon pea plus maize $(\mathrm{P}+\mathrm{M})$ and lablab plus maize $(\mathrm{L}+\mathrm{M})$ systems as measured by dry combustion and Kjeldahl methods.

\begin{tabular}{|c|c|c|c|c|}
\hline \multirow{2}{*}{ Method } & \multicolumn{3}{|c|}{ No N } & With $\mathrm{N}$ \\
\hline & Bare soil & $\mathrm{P}+\mathrm{M}$ & $\mathrm{L}+\mathrm{M}$ & $\mathrm{P}+\mathrm{M} \quad \mathrm{L}+\mathrm{M}$ \\
\hline & \multicolumn{4}{|c|}{ - } \\
\hline Dry combustion & $3.3 \mathrm{~B}$ & $4.8 \mathrm{Aa}$ & 4.9 Аа & 5.3 a 5.4 a \\
\hline Kjeldahl & $3.0 \mathrm{~B}$ & $4.5 \mathrm{Aa}$ & $4.8 \mathrm{Aa}$ & 5.1 a 5.2 a \\
\hline
\end{tabular}

${ }^{a}$ Values in rows followed by the same capital letter, in the same $\mathrm{N}$ level, do not differ (Tukey test, $P=0.05$ ). This is a comparison between cropping systems. Values in rows followed by the same small letter, in the same cropping system, do not differ (Tukey test, $P=0.05)$. This is a comparison between $\mathrm{N}$ levels.

sis in Rio Grande do Sul (Tedesco et al., 1995) (Figure 3c). This poor correlation for the $\mathrm{C}: \mathrm{N}$ ratio as compared to the high correlations for $\mathrm{C}$ and $\mathrm{N}$ may be a result from the division operation to obtain $\mathrm{C}: \mathrm{N}$ values, which possibly amplifies the distortions between the two methods.

There was a tendency for the $\mathrm{C}: \mathrm{N}$ ratio calculated from non-corrected Walkley-Black-C and Kjeldahl-N to underestimate the ratio calculated from dry combustion, above the value of 9.5 (Figure 3a). On the other hand, the $\mathrm{C}: \mathrm{N}$ ratio calculated from the corrected Walkley-Black-C $\left(\mathrm{C}=1.05 \mathrm{C}_{\text {w.Black }}+0.47\right)$ and Kjeldahl-N overestimated the C: $\mathrm{N}$ ratio from dry combustion, for values below 14.0, which are the common C: $\mathrm{N}$ ratios for soils. These results are indications that the absolute $\mathrm{C}: \mathrm{N}$ ratio values should be interpreted with caution, since under- or overestimations can occur in relation to the real value according to the employed methodological procedure. But in spite of this, there is a clear tendency for samples with high C:N ratios analyzed according to wet methods, also show high C:N ratios analyzed according to dry combustion, and vice versa. 

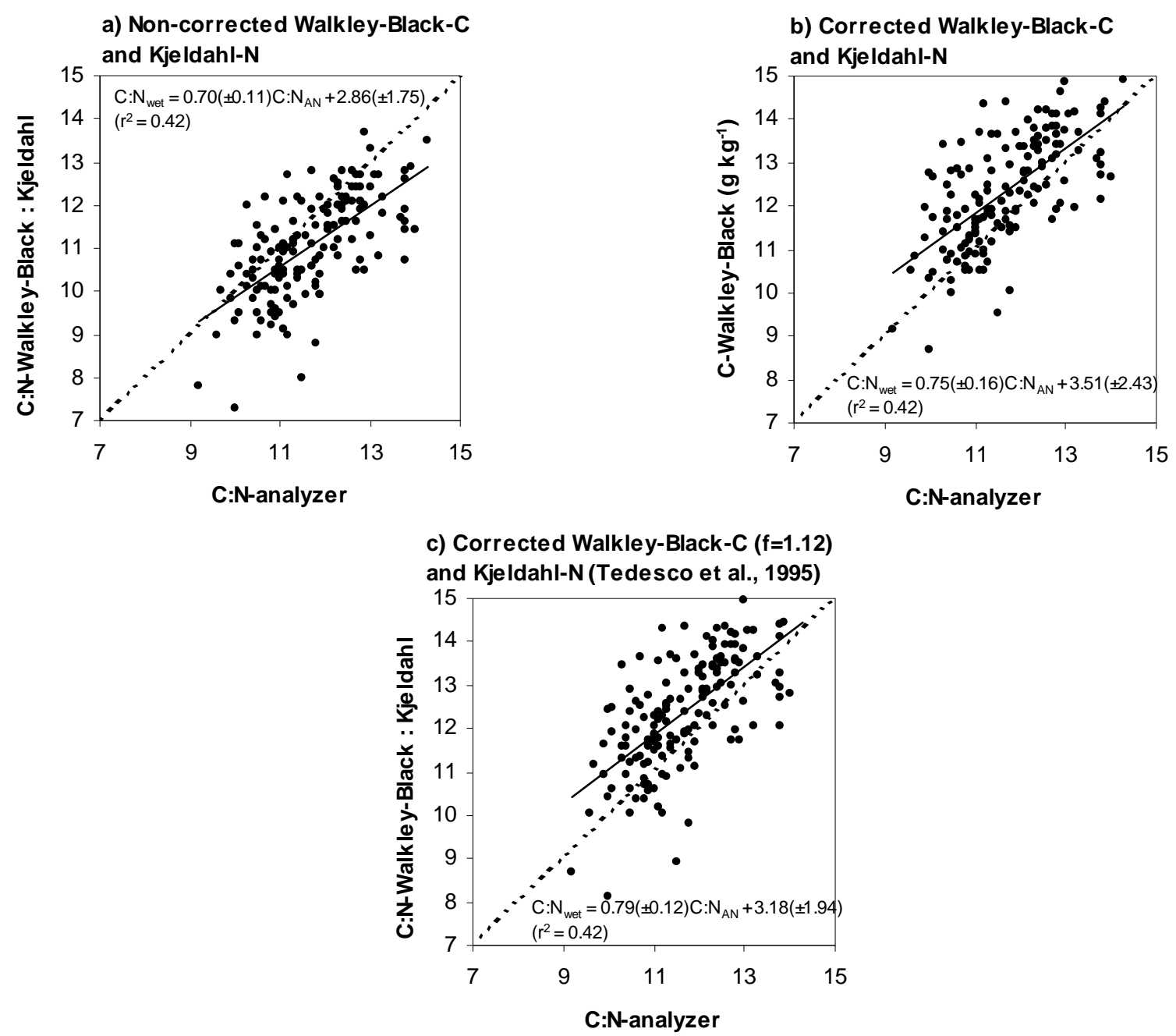

Figure 3 - Relationships between the C:N ratio values obtained by the Walkley-Black and Kjeldahl methods and the C:N ratio values obtained by dry combustion, considering (a) the non-corrected Walkley-Black C and the Kjeldahl N, (b) the corrected Walkley-Black C $\left(\mathrm{C}=1.053 \mathrm{C}_{\text {w.Black }}+0,470\right)$ and the Kjeldahl N, and (c) the corrected Walkley-Black C using the factor 1.12 suggested by Tedesco et al. (1995) for soils of Rio Grande do Sul and the Kjeldahl N ( $\mathrm{n}=150)$. “C: $\mathrm{N}_{\text {wet }}$ " means C:N ratio calculated from Walkley-Black and Kjeldahl, “C: $\mathrm{N}_{\mathrm{AN}}$ ” means $\mathrm{C}: \mathrm{N}$-analyzer. The values in parenthesis following the \pm signal refer to the confidence interval $(P<0.05)$ of the angular or linear coefficient of the regression.

\section{CONCLUSIONS}

The C concentration determined by WalkleyBlack and the $\mathrm{N}$ concentration determined by Kjeldahl methods obtained for this kaolinitic Paleudult profile highly correlate to the respective results of $\mathrm{C}$ and $\mathrm{N}$ concentrations determined through the automated dry combustion method (Elementar Vario EL), and, the correction equation ( $\mathrm{C}=$ $1.05 \mathrm{C}_{\text {W.Black }}+0.47$ ) is suggested to be applied on results of $\mathrm{C}$ obtained by Walkley-Black. The results of $\mathrm{N}$ obtained by Kjeldahl methods did not need correction.

The methods for $\mathrm{C}$ and $\mathrm{N}$ determination did not affect the interpretation of the effects of management systems on soil $\mathrm{C}$ and $\mathrm{N}$ stocks, indicating that both methodological approaches provide comparable conclusions in soil organic matter studies in different management systems.

The C: $\mathrm{N}$ ratio results obtained after WalkleyBlack and Kjeldahl methods have a poor correlation to results obtained after dry combustion technique. Possibly the deviations between results of Walkley-Black $\mathrm{C}$ and dry combustion $\mathrm{C}$ and the deviations between results of Kjeldahl $\mathrm{N}$ and dry combustion $\mathrm{N}$ were magnified after the calculation of $\mathrm{C}: \mathrm{N}$ ratios.

\section{ACKNOWLEDGEMENTS}

To J. A. Zanatta, for her collaboration on statistical analysis and to CNPq for providing scholarships to J. Mielniczuk, C. Bayer and D.P. Dick. CAPES and 
DAAD are acknowledged for supporting the Probral project, in the framework of which this study was carried out. To FAPERGS, for financial support in the framework of the project PRONEX.

\section{REFERENCES}

BAYER, C. Dynamics of soil organic matter in management systems. Porto Alegre: UFRGS, 1996. 241p. (Thesis Ph.D.).

BLAKE, G.R.; HARTAGE, K.H. Bulk density. In: KLUTE, A. (Ed.). Methods of soil analysis. Part 1. Physical and mineralogical methods. Madison: SSSA, 1986. p.363-375.

BRASIL. Ministério da Agricultura. Levantamento de reconhecimento dos solos do Rio Grande do Sul. Recife: Convênio MA/DPP - SA/DRNR, 1973. 431p.

BREMNER, J.M. Organic forms of nitrogen. In: BLACK, C.A. (Ed.). Methods of soils analysis. Part 2. Chemical and microbiological properties. Madison: SSSA, 1965. p.1238-1255.

BREMNER, J.M.; SHAW, K. Denitrification in soil. I. Methods of investigation. Journal of Agricultural Science, v.51, p.2239, 1958.

BRYE, K.R.; SLATON, N.A. Carbon and nitrogen storage in a Typic Albaqualf as affected by assessment method. Communications in Soil Science and Plant Analysis, v.34, p.1637-1655, 2003

DIAZ-ZORITA, M. Soil organic carbon recovery by the WalkleyBlack method in a Typical Hapludoll. Communications in Soil Science and Plant Analysis, v.30, p.739-745, 1999.

DIEKOW, J.; MIELNICZUK, J.; KNICKER, H.; BAYER, C.; DICK, D.P.; KÖGEL-KNABNER, I. Soil C and N stocks as affected by cropping systems and nitrogen fertilization in a southern Brazil Acrisol managed under no-tillage for 17 years. Soil and Tillage Research, v.81, p.87-95, 2005.
GEE, G.W.; BAUDER, J.W. Particle-size analysis. In: KLUTE, A. (Ed.). Methods of soil analysis. Part 1. Physical and mineralogical methods. Madison: SSSA, 1986. p.383-411.

INTERGOVERNMENTAL PANEL ON CLIMATE CHANGE IPCC. Revised 1996 IPCC Guidelines for National Greenhouse Gas Inventories: The workbook. Geneva: IPCC, 1996.

McGEEHAN, S.L.; NAYLOR, D.V. Automated instrumental analysis of carbon and nitrogen in plant and soil samples. Communications in Soil Science and Plant Analysis, v.19, p.493-505, 1988.

MIKHAILOVA, E.A.; NOBLE, R.R.P.; POST, C.J. Comparison of soil organic carbon recovery by Walkley-Black and dry combustion methods in the Russian Chernozem. Communications in Soil Science and Plant Analysis, v.34, p.1853-1860, 2003.

NELSON, P.W.; SOMMERS, C. E. Total C, organic C and organic matter. In: PAGE, A.L. (Ed.). Methods of soil analysis. Part 2. Chemical methods. Madison: SSSA, 1996. p.539-579.

PÉREZ, D.V.; ALCANTARA, S.; ARRUDA, R.J.; MENEGHELLI, N.A. Comparing two methods for soil carbon and nitrogen determination using selected Brazilian soils. Communications in Soil Science and Plant Analysis, v.32, p.295-309, 2001.

STEWART, B.A.; PORTER, L.K.; CLARK, F.E. The reliability of a micro-dumas procedure for determining total nitrogen in soil. Soil Science Society of America Proceedings, v.27, p.377380, 1963.

TEDESCO, M.J.; GIANELLO, C.; BISSANI, C.A.; BOHNEN, H.; VOLKWEISS, S.J. Análise de solo, plantas e outros materiais. 2.ed. Porto Alegre: UFRGS, 1995. 174p.

Received November 30, 2005

Accepted June 22, 2007 